\title{
Hypoxia and cyanobacteria blooms - are they really natural features of the late Holocene history of the Baltic Sea?
}

\author{
L. Zillén and D. J. Conley \\ Department of Earth and Ecosystem Sciences, Lund University, Sölvegatan 12, SE-223 62 Lund, Sweden
}

Received: 3 March 2010 - Published in Biogeosciences Discuss.: 15 March 2010

Revised: 29 July 2010 - Accepted: 18 August 2010 - Published: 31 August 2010

\begin{abstract}
During the last century (1900s) industrialized forms of agriculture and human activities have caused eutrophication of Baltic Sea waters. As a consequence, the hypoxic zone in the Baltic Sea has increased, especially during the last 50 years, and has caused severe ecosystem disturbance. Climate forcing has been proposed to be responsible for the reported trends in hypoxia $\left(<2 \mathrm{mg} / \mathrm{l} \mathrm{O}_{2}\right)$ both during the last c. 100 years (since c. $1900 \mathrm{AD}$ ) and the Medieval Period. By contrast, investigations of the degree of anthropogenic forcing on the ecosystem on long time-scales (millennial and greater) have not been thoroughly addressed. This paper examines evidence for anthropogenic disturbance of the marine environment beyond the last century through the analysis of the human population growth, technological development and land-use changes in the drainage area. Natural environmental changes, i.e. changes in the morphology and depths of the Baltic basin and the sills, were probably the main driver for large-scale hypoxia during the early Holocene (8000-4000 cal yr BP). We show that hypoxia during the last two millennia has followed the general expansion and contraction trends in Europe and that human perturbation has been an important driver for hypoxia during that time. Hypoxia occurring during the Medieval Period coincides with a doubling of the population (from c. 4.6 to 9.5 million) in the Baltic Sea watershed, a massive reclamation of land in both established and marginal cultivated areas and significant increases in soil nutrient release. The role of climate forcing on hypoxia in the Baltic Sea has yet to be demonstrated convincingly, although it could have helped to sustain hypoxia through enhanced salt water inflows or through changes in hydrological inputs. In addition, cyanobacteria blooms are not natural features of the Baltic Sea as previously deduced, but are a consequence of enhanced phosphorus release from the seabed that occurs during hypoxia.
\end{abstract}

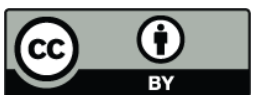

Correspondence to: L. Zillén (lovisa.zillen@geol.lu.se)

\section{Introduction}

Eutrophication and associated hypoxia, defined as $<2 \mathrm{mg} / \mathrm{l}$ dissolved oxygen, have one of the largest impacts on the health of the Baltic Sea ecosystem (HELCOM, 2007). The area covered by laminated sediments (indicative of hypoxia) in the Baltic Sea (Fig. 1) is estimated to have increased about four times since 1960 (Jonsson et al., 1990) due to surplus loads of nutrients (nitrogen and phosphorus) from anthropogenic sources (Wulff et al., 2007). Hypoxia alters nutrient biogeochemical cycles (Vahtera et al., 2007), it causes large ecosystem disturbances and may be the single strongest factor affecting the biodiversity of the macrobenthic communities, disrupting benthic food webs in the Baltic basin (Karlson et al., 2002; Conley et al., 2009a). Hypoxia results in a high internal load of phosphorus released from sediments, which causes low nitrogen/phosphorus (N/P) ratios in surface waters during summer; a factor that favors cyanobacterial blooms (Vahtera et al., 2007).

There is currently considerable public concern over the rate of climate change and recent human impact on the Baltic Sea. However, notions that human activity could have influenced the Baltic Sea on longer time-scales (i.e. centennial and millennial) have not been systematically addressed. A common perception is one of a naturally eutrophic and enclosed sea, which has regularly experienced hypoxia and cyanobacteria blooms throughout its history (Bianchi et al., 2000). Another different, but widely-held view is that the Baltic Sea was a pristine oligotrophic clear-water sea prior to the turn of the last century, i.e. $1900 \mathrm{AD}$ (Österblom et al., 2007; Savchuk et al., 2008). This latter view has become especially prevalent in discussions regarding the establishment of "reference" or "background" conditions that can be targeted in the future for management actions.

But how pristine was the pre-1900 Baltic Sea and how much variability did the basin experience while in a "natural" state? To what degree did early human impact alter the bottom water oxygen conditions, and how do previous

Published by Copernicus Publications on behalf of the European Geosciences Union. 


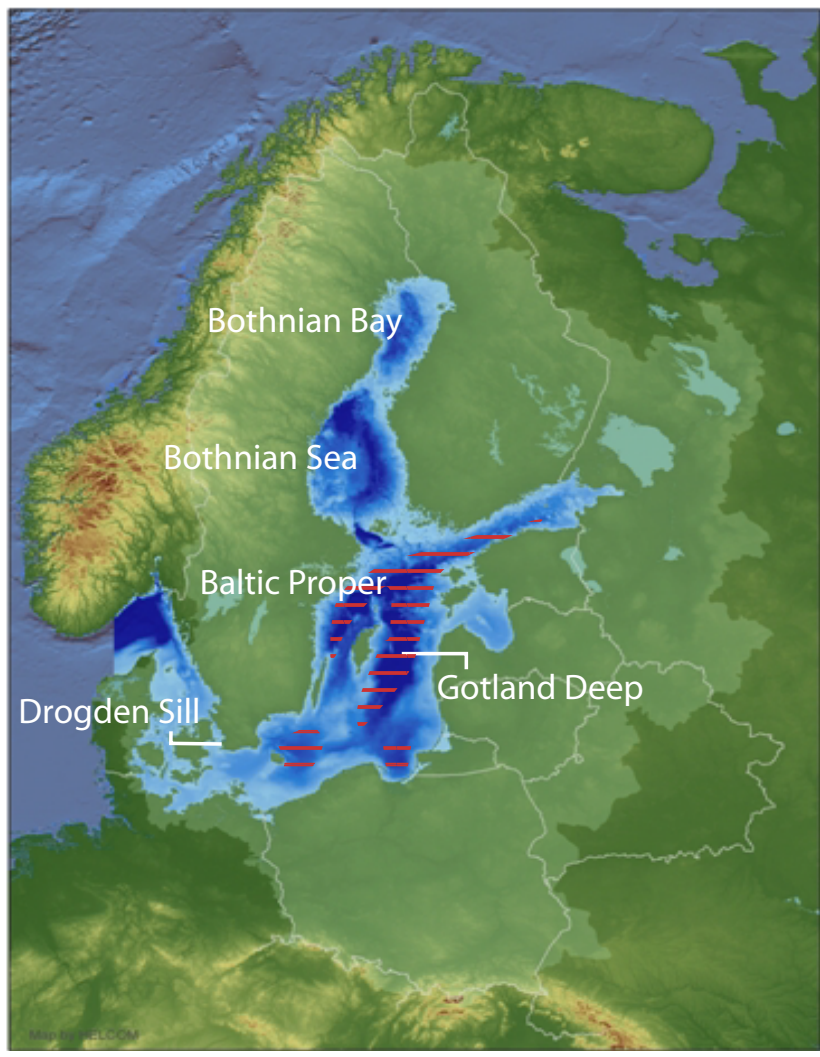

Fig. 1. Map of the Baltic Sea identifying its major sub-basins (Bothnian Bay, Bothnian Sea and Baltic Proper) and the major sill in the inlet area (Drogden Sill). The red lines designate the maximum hypoxic area that occurs in the Baltic Sea. Hypoxia is common in the deeper basins of the Baltic Proper where a permanent restricts the ventilation of the deeper waters and supports the development of persistent hypoxia (Conley et al., 2009a). The low salinity waters of the Bothnian Sea and, in particular, the Bothnian Bay have weaker haloclines and better ventilation. In combination with a lower productivity this better ventilation makes these basins mostly oxic. Also, the Baltic Sea drainage area in light green, where 85 million people live today.

alterations compare to those caused by the more recent impact? To answer these questions requires knowledge of past climate and environmental variability, but also detailed understanding of long-term human impact upon terrestrial and aquatic ecosystems. Although it may be difficult to separate natural and human-induced changes of ecosystems, it is possible to critically examine and consider all supporting evidence.

Humans have always affected their environment, including substantial impacts on the movement and transport of elements, such as the essential nutrients $\mathrm{C}, \mathrm{P}$ and $\mathrm{N}$ (Schlesinger, 2004). The most significant impacts of humankind on nature have been deforestation (Kaplan et al., 2009) and expansion of agricultural land (Pongratz et al., 2008) starting already in pre-historic time. Paleoecologists, therefore, routinely describe and account for human impact over millennia to discriminate between the effects of climate change and human activity on the environment. Human forcing (via eutrophication) of aquatic ecosystems has been reconstructed by various paleoecological studies in the Baltic Sea drainage area (e.g. Renberg et al., 2001; Bradshaw et al., 2005). Nevertheless, it is not often appreciated that significant human impact on the Baltic Sea watershed occurred almost two millennia ago. As a consequence, most previous palaeoenvironmental research has focused on ecosystem responses to climate forcing (Andrén et al., 2000; Bianchi et al., 2000; Leipe et al., 2008), although a few studies have investigated anthropogenic influences during the last c. 100 years (Risberg, 1990; Andrén, 1999; Savage et al., 2010). Thus, there is thus a need to assess the degree of human forcing on the Baltic Sea and the ecosystem functioning and resilience, on both historical and recent time-scales.

A recent review of hypoxia in the Baltic Sea has defined periods of hypoxia in the geological record during the majority of the Holocene (Zillén et al., 2008). They suggested that there may a correlation between climate variability in the past and the state of the marine environment where periods of hypoxia coincided with intervals of warmer climate conditions, such as the Holocene Thermal Maximum (HTM c. 90005000 cal yr BP), the Medieval Warm Period (MWP c. 800$1200 \mathrm{AD}$ ) and the observed warming that occurred during most of the 20th century AD (Zillén et al., 2008). However, the latter study also identified relationships between the occurrence of hypoxia and human population growth and large-scale changes in land use that occurred in much of the watershed during the early-Medieval expansion (700 $1300 \mathrm{AD}$ ) and the Industrial Revolution (intensifying around 1850 AD). This conclusion implies that anthropogenic impacts may have been an important driving factor for hypoxia during the last two millennia (Zillén et al., 2008).

In this paper, we will explore this hypothesis further and show that relatively recent hypoxia in the Baltic Sea is human induced and that cyanobacteria blooms are a consequence of enhanced phosphorus release that occurs together with hypoxia. We delineate the level of population growth, technological development and cultural landscape changes during the last two millennia and their implications for the presence of past hypoxia. This study challenges the hypothesis that the occurrence of hypoxia in the past was climate related. We will demonstrate the sensitively of this large enclosed sea to anthropogenic perturbations on centennial and millennial time-scales.

\section{Occurrence of hypoxia in the Baltic Sea}

The Baltic Sea has experienced large environmental changes since the onset of the last deglaciation of the Scandinavian ice-sheet around 17000-15000 cal yr BP (Björck, 
1995). These changes were caused by variations in climate, deglaciation processes and a complex interplay between global sea-level changes and regional land-uplift (for more detailed information see e.g. Björck, 1995, 2008). One of the largest environmental changes during the Holocene was the transformation of the basin from a freshwater lake (the Ancylus Lake c. 10 700-10 000 cal yr BP) to a full brackish estuarine circulation system, the Littorina Sea, around $8000 \mathrm{cal}$ yr BP. During the first phase of the Littorina Sea (c. 8000-6000 cal yr BP) the opening of The Sound (or Drogden Sill) where salt water enters the Baltic Sea was about twice its size compared to today (Gustafsson and Westman, 2002) and the surface waters of the Baltic were more saline, i.e. 10-15, than the present 7-8 (Gustafsson and Westman, 2002; Berglund et al., 2005). Not until c. 4000 cal yr BP did salinity began to decrease significantly, as the opening was reduced in size due to isostatically induced sea level changes (Gustafsson and Westman, 2002). Throughout the late Holocene history of the Baltic Sea, i.e. the last c. $3000 \mathrm{yr}$, the main physical and oceanographic properties of the basin have remained relatively unchanged and similar to present marine conditions.

Today, the Baltic Sea is an estuarine brackish water-body with limited water exchange with the adjacent Kattegat and its sub-basins. Its estuarine circulation retains nutrients and organic matter within the basin leading to high nutrient availability and eutrophication of waters, which makes the Baltic Sea ecosystem highly susceptible to hypoxia (Conley et al., 2009a). The Baltic Sea ecosystem is sensitive to changes in both $\mathrm{N}$ and $\mathrm{P}$ inputs (Conley et al., 2009b). High Navailability increases the spring blooms of phytoplankton (which is favored by a high N:P ratio) enhancing oxygen consumption in the bottom waters. During low bottom water oxygen conditions redox-sensitive phosphorus is released from the sediments, resulting in increased phosphate concentrations in the water column. This increase completes a positive feedback loop between P-availability, cyanobacteria blooms during summers (which is favored by a low $\mathrm{N}: \mathrm{P}$ ratio) and increased hypoxia and it amplifies eutrophication (Conley et al., 2002). The current release of phosphate from sediments is an order of magnitude larger than anthropogenic inputs (Conley et al., 2009a).

The estuarine circulation also results in a north-south salinity gradient, a vertical density stratification of the water mass and the formation of a strong halocline between the salt-rich marine waters entering the system from Kattegat and the surplus freshwater from the watershed. The stratification prevented vertical mixing of the water column and limited the convection of more oxygen-rich waters to the bottom, especially in the deeper depressions ( $>200 \mathrm{~m}$ ) with limited circulation (Conley et al., 2009a). It has been demonstrated that short term trends in hypoxia during the modern era in the Baltic Sea are related to variations in salt water inflows from Kattegat, with less stratification and less hypoxia during "stagnation periods" (i.e. in the 1920/1930s, 1950/1960s and the 1980/1990s). During these "stagnation periods" the salt water inflows are reduced and the salinity of the Baltic Sea decreases by about 0.5 salinity units lower than the mean value (Meier and Kauker, 2003).

During the Holocene, there have been three major periods of hypoxia in the deeper depressions of the Baltic Proper; during the early Littorina Sea (c. $8000-4000$ cal yr BP) during the middle Late Littorina Sea (c. 2000-800 cal yr BP) and during the last c. 100 years (or since $1900 \mathrm{AD}$; Fig. 2) although an expansion of the hypoxic zone after 1950 has occurred. During the early Littorina Sea hypoxia in the Baltic Proper between 8000-4000 cal yr BP can be explained by the relative high salinity, which would result in a strong salinity stratification of the water column and limited ventilation of oxygen to deeper waters (Gustafsson and Westman, 2002). It may be argued that natural environmental changes (i.e. changes in the morphology and depths of the Baltic basin and the sills) and not climate variability were the main triggers for millennial scale changes in hypoxia during the early Holocene. During this initial and more saline development of the Littorina Sea hypoxia was also present in the northern Baltic Sea (Bothnian Sea and Bothnian Bay; Zillén et al., 2008) where salinities of 7-8 (similar to the present Baltic Proper) have been reconstructed (Widerlund and Andersson, 2006). The salinity gradually decreased throughout the Littorina Sea and the halocline in the northern Baltic Sea diminished, as well as, bottom water oxygen depletion.

Hypoxia in the Baltic Proper during the last 2 millennia does not show a relationship to any known changes in salinity (Fig. 2). During this time, the surface salinity in the Baltic Proper probably ranged between $7-8$, i.e. similar to the modern era (Gustafsson and Westman, 2002). However, the periods of hypoxia correlate to population growth and large-scale changes in land use that occurred in the Baltic Sea watershed during the early-Medieval expansion between 800-1300 AD and the beginning of the Industrial Revolution at $1850 \mathrm{AD}$ in northwestern Europe (Fig. 2). In contrast, more oxic conditions in the Baltic Sea between c. 1300-1500 AD correspond to population declines and farm desertion in Europe that took place at the beginning of the late-Medieval crisis (Andersson Palm, 2001; Antonson, 2009). Furthermore, geological evidence identifies the Medieval Period as the interval of maximum sediment carbon sequestration, highest nitrogen accumulation and chlorophyll concentrations during the entire Littorina phase, indicating more productive conditions (Voss et al., 2001). The oceanographic conditions during the Medieval Period cannot explain this productive phase and persistent hypoxia, and why it should differ (i.e. be more productive) from the period of oxygen deficency during the early Littorina Sea when temperatures and salinities were even higher as a response to the larger inlet area (Gustafsson and Westman, 2002) and the Holocene Thermal Maximum (Snowball et al., 2004). Consequently, salinity and temperatures cannot explain hypoxia during the Medieval period. Therefore, the late Holocene record of hypoxia in the Baltic 


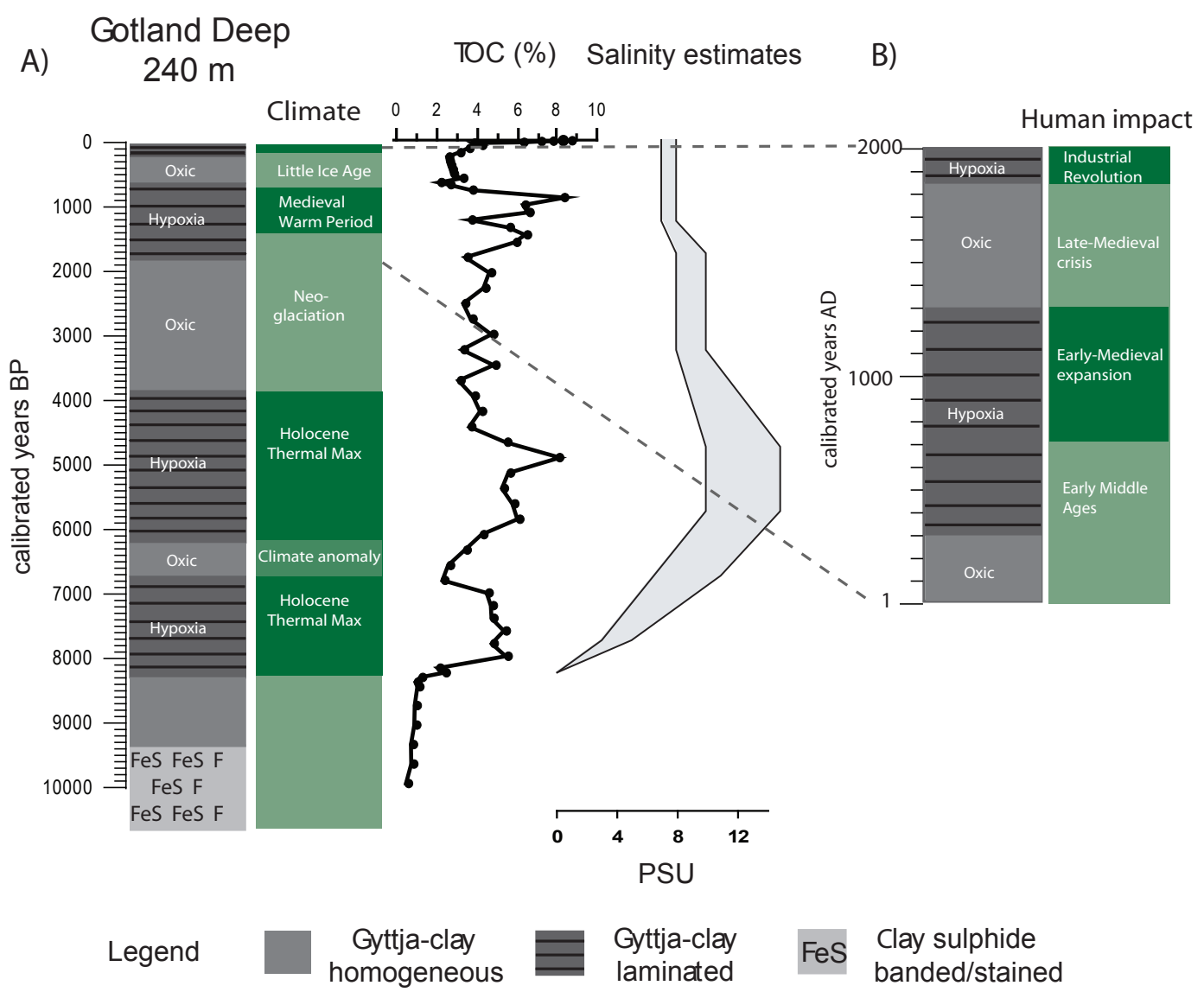

Fig. 2. (A) Figure showing the occurrence of laminated sediments, total organic carbon content (TOC) and salinity estimates, plotted against a calendar year time scale, based on a compilation of sediment records from the Baltic proper (Zillén et al., 2008). The sediment records suggest that during the last c. 8000 cal yr BP hypoxia has occurred intermittently in the deeper sub-basins in the Baltic Proper. The hypoxia during the early Littorina Sea ( $8000-4000$ cal yr BP) coincides with intervals of maximum salinity estimates and high TOC values. Hypoxia during the last two millennia does not correlate to any alterations in salinity but to maximum TOC contents during the Medieval Warm Period (MWP) and the last c. 100 years. (B) The figure shows the same sediment records as in (A), but compared to anthropogenic expansion and contraction phases. The coherency between the two latter records suggest that human impact is just a strong potential independent forcing mechanism on increased productivity and hypoxia as climate changes during the late Holocene history of the Baltic Sea. Note that due to the poor chronological control associated with Baltic Sea sediments the age error estimates of the periods of hypoxia the last 2000 years are approximately \pm 500 years (Zillén et al., 2008). The non-overlap between the period of hypoxia centered at c. 1000 AD and the intervals of climate/human impact changes may thus be due to dating errors.

Sea may not have a natural cause, but result from anthropogenic impacts (Zillén et al., 2008).

\section{Addressing human impact variability in the Baltic Sea watershed during the last two millennia}

\subsection{Population dynamics}

Quantitative pre-historic population data is sparse and often associated with relative large uncertainties. The source of population data in this study is the Atlas of World Population History by McEvedy and Jones (1978) which is largely acknowledged in recent literature (e.g. Pongratz et al., 2008) and stands out through its consistency and high spatial and temporal resolution.

The population data show that Europe has experienced long-term demographic expansion and contraction during the last two millennia (Table 1; McEvedy and Jones, 1978). Characteristic for this period is a phase of low population levels during the plague epidemics c. 300-500 AD, which was followed by a population increase and expansion during the early-Medieval, most prominent from 1000 to $1300 \mathrm{AD}$ but starting already in the 7th century AD (Fig. 3). For example, in Sweden and Denmark the number of villages at least doubled during the latter time interval (Lagerås, 2007). Subsequently, this population expansion was followed by a significant contraction in the late 14th century (late-Medieval 
Table 1. Total population data for Europe (McEvedy and Jones, 1978) and the Baltic Sea area. Please note that the population estimates for the Baltic Sea drainage area are based on the assumption that the population in the Baltic region has always been approximately $12 \%$ of the total European population (i.e. as during the modern time period).

\begin{tabular}{rlll}
\hline Year AD & Population level in Europe & $\begin{array}{l}\text { European population } \\
\text { estimates (McEvedy and } \\
\text { Jones, 1978) in millions }\end{array}$ & $\begin{array}{l}\text { Tentative population } \\
\text { estimates (Baltic Sea } \\
\text { area) in millions }\end{array}$ \\
\hline $400-1000$ & Stable at a low level & $25-30$ & $3-3.6$ \\
$1000-1300$ & Population boom and expansion & From 38 to 79 & From 4.6 to 9.5 \\
$1300-1350$ & Stable at a high level & $79-80$ & 9.6 \\
$1350-1420$ & Steep decline & From 80 to 60 & From 9.6 to 7.2 \\
$1420-1470$ & Stable at a low level & 60 & 7.2 \\
$1470-1500$ & Expansion to 1350 AD values & 81 & 9.7 \\
$1500-1700$ & Slow expansion gaining momentum & From 81 to 120 & From 9.7 to 14.4 \\
& in the early 16th century. & From 120 to 731 & From 14.4 to 85 \\
\hline $1700-2005$ & Population boom and expansion & From
\end{tabular}
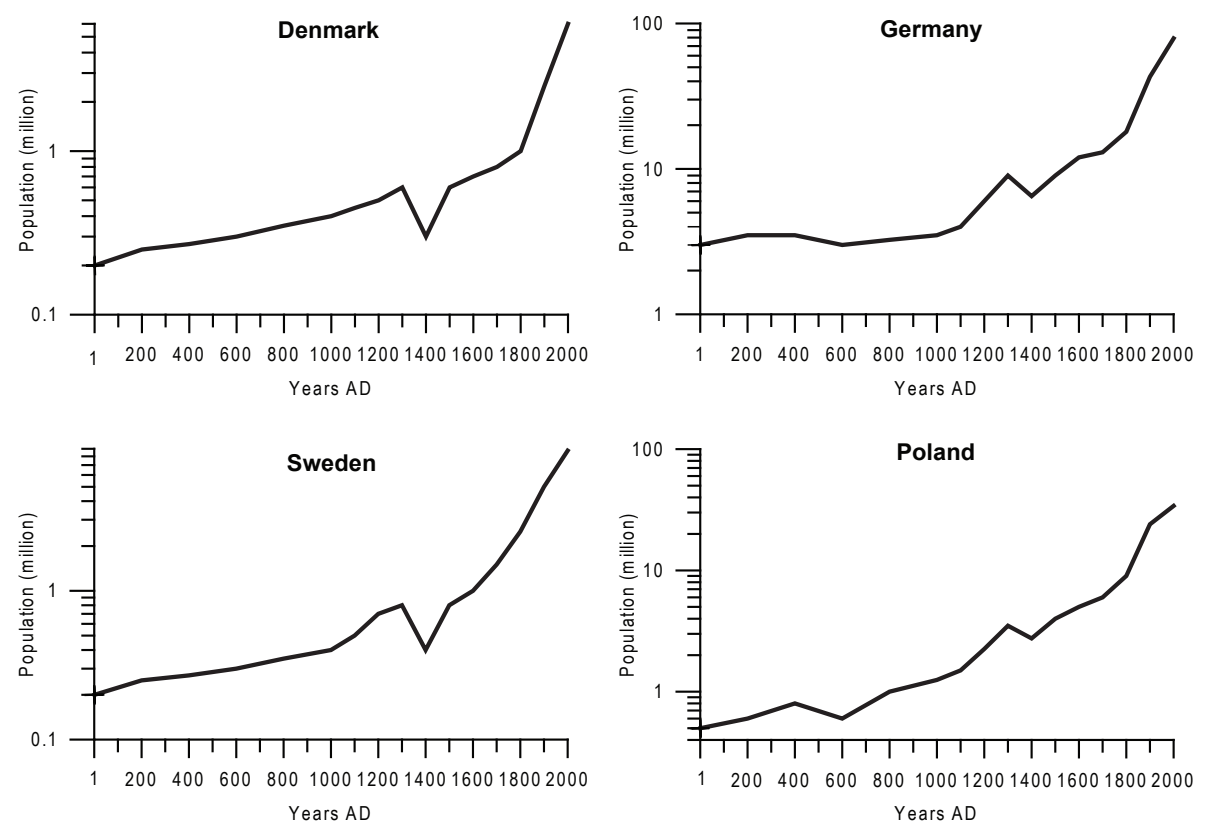

Fig. 3. Estimates of the total population of some the Baltic Sea countries i.e. Denmark, Germany, Sweden and Poland since 1 AD (McEvedy and Jones, 1978). Note the rapid increase between 700-1300 AD, followed by an equal prompt decrease in the early 14th century, in all of the countries.

crisis) and a new period of growth in association with the beginning of the first Industrial Revolution from approximately $1700 \mathrm{AD}$ (Table 1). In post $1700 \mathrm{AD}$-time, the most rapid population increase took place after the start of the second Industrial Revolution around $1850 \mathrm{AD}$, when technological and economic progress gained momentum with the development of steam-powered ships and railways.

In the majority of the countries in the Baltic Sea region, the early-Medieval time included a doubling of population over a period of less than c. $300 \mathrm{yr}$ (Fig. 3). This rapid increase in population is believed to be a result of the Medieval economic expansion and growth in agricultural production (Myrdal, 1997 and Sect. 3.2).

The period of stagnation and population decline that followed the early-Medieval expansion in the late 14th and early 15 th centuries was mainly due to the loss of life during famines and the Black Death. In AD 1400 the population of Europe was less than $25 \%$ below its early-Medieval peak. In many countries the decline was even more catastrophic (Fig. 3). Data from Sweden suggests that the population decreased from 1100000 to 347000 (c. 68\%) between $1300 \mathrm{AD}$ and $1413 \mathrm{AD}$ (Andersson Palm, 2001). In 
Germany, the population decline reached around 55\% in some regions (Simms, 1976). This period is also known as the late-Medieval agricultural crisis and was characterized by decreased total agricultural production and abandonment of farms (Simms, 1976; Lagerås, 2007; Antonson, 2009). A compilation of field surveys and studies of historical maps alongside conventional written sources suggests a rate of farm desertion in Sweden around 57-58\% (Antonson, 2009). It was shown that the late-Medieval desertion was not only high in marginal agricultural areas, but also in more fertile areas with a long history of settlement continuity (Simms, 1976). In addition, population development (increase or decrease) has served as a main driver for agricultural expansion and contraction during the last two millennia and has had an impact on all levels of society (Lagerås, 2007). However, the population rise during the Medieval expansion would not have been possible without the Medieval agricultural revolution, in which new agricultural tools, implements and techniques were introduced.

\subsection{Technological development}

Technological developments have had major impacts on agriculture during the last two millennia. One of the largest impacts on agricultural soils is plowing (Dawson and Smith, 2007). Plow tillage loosens the soil, buries crop residues and exposes the soil to rainfall and winds that result in erosion. Water runoff removes topsoils, nutrients $(\mathrm{P}$ and $\mathrm{N})$ and soil organic carbon (C) derived from manure and fertilizers, and transports them to water bodies, such as rivers and streams, and finally into coastal zones (Whitmore et al., 1992; Dawson and Smith, 2007; Ulén et al., 2007). Accelerated erosion is one of the major causes of agriculture soil degradation and eutrophication of water bodies. It often results in irreversible impacts on the cycles of soil $\mathrm{C}, \mathrm{P}$ and $\mathrm{N}$ and aquatic ecosystem health (Dawson and Smith, 2007; Ulén et al., 2007).

The first plow (the ard) was made of wood, and was a simple digging stick or a paddle-shaped spade that could be pulled by humans or animals. The greater availability of iron allowed for stronger, sharper and more efficient implements to be used. The ard evolved into the "Roman plow" around $1 \mathrm{AD}$ with an iron share and was widely used in Europe about $500 \mathrm{AD}$ (Lal et al., 2007). The Roman plow subsequently developed into a soil-inverting plow (or moldboard) around 800-1000 AD (Lal et al., 2007) and was widely used on fertile plains while the more stony upland areas in e.g. Sweden were managed with iron spades and ards all the way up to the beginning of the 20th century (Lagerås, 2007). The largest change to the moldboard plow was that the soil could ride up the moldboard and be inverted (similar to the modern moldboard plows). This change made the soil more exposed to rain and wind erosion. With the introduction of the soilinverted moldboard plow, accelerated erosion and agriculture soil degradation progressed (Lal et al., 2007).

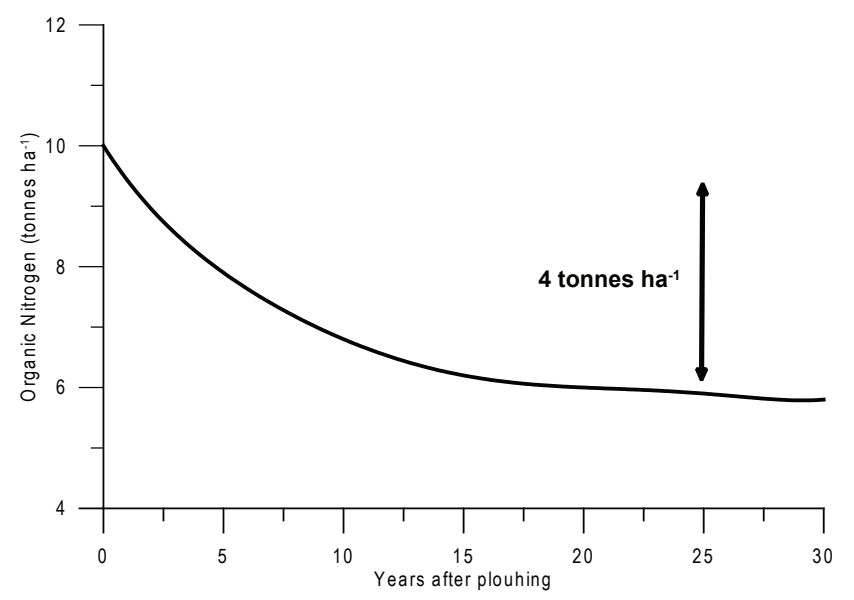

Fig. 4. Losses of soil organic nitrogen as a function of number of years after plowing permanent grassland in a temperate climate zone (UK). After 20 years, c. $4 \mathrm{t} \mathrm{Nha}^{-1}$ had leached from the natural soil, $50 \%$ of that in the first 5.5 years (after Whitmore et al., 1992).

The majority of the carbon in the global terrestrial pool is stored in soils (Dawson and Smith, 2007). Arable soils contain less organic carbon than, for example, grasslands (Smith et al., 1996; Freibauer et al., 2004; Dawson and Smith, 2007). Long-term experiments show that converting grassland to arable agriculture can result in a $20-50 \%$ loss of soil organic $\mathrm{C}$ over an initial period of $15-20 \mathrm{yr}$ (Whitmore et al., 1992; Smith et al., 1996). In addition, plowing permanent grassland can lead to increases in organic nitrogen leaching of c. $4 \mathrm{t} \mathrm{Nha}^{-1}$ over 20 years, $50 \%$ of it in the first 5.5 years (Fig. 4; Whitmore et al., 1992). The organic nitrogen lost through plowing is mineralized to inorganic nitrogen, which may be denitrified or leached as bioavailable nitrate $\left(\mathrm{NO}_{3}^{-}\right)$. Nitrate leaching commonly represents the single greatest loss of nitrogen from soil systems (Cameron and Haynes, 1986). For example, Whitmore et al. (1992) showed that the mineralization of organic nitrogen from plowing grasslands released a substantial amount of nitrate ( 25 billion $\mathrm{kg}$ ) between 1940 and 1990 in England and Wales increasing the concentration of nitrate in drainage waters by more than $40 \mathrm{mg} \mathrm{NO}_{3}^{-} / 1$. Phosphorous release also increases with plowing, given that the soil content of organic $\mathrm{P}$ is primarily a function of its organic carbon content (Ulén et al., 2007). P is also more likely to be carried from the soil on colloidal or particulate matter rather than in solution (particulate P can amount to about $80 \%$ of the total P losses) and the greatest losses of particulate $\mathrm{P}$ from the soil occurs by surface run-off and erosion (Feller, 2009).

It should be recognized that forestry and deforestation also causes losses of soil organic C, N and P (Likens and Bormann, 1995). The magnitude of soil organic carbon depletion may be 25 to $50 \%$ in temperate climates during the first 5 to 20 years following deforestation (Lal, 2004). Significantly 
enhanced increases in both dissolved and particulate fluxes occur through deforestation with disruption of the cycle of uptake and retention in forests and the mechanisms are multifold (Feller, 2009). Due to less vegetation cover after forest clearance surface runoff may increase. The increase in runoff may, in combination with soil disturbance, induce erosion and increase sediment transport into surface waters. Clearcutting, which is common in Scandinavia, greatly increases the rates of leaching (Löfgren et al., 2009).

Land-use changes during the Medieval expansion (clearance of grassland and forest etc.; Kaplan et al., 2009) and the Industrial Revolution in Europe (tiling and rapid expanded forest industry etc.) are known to have increased the rate of total phosphorus (TP) loading to aquatic ecosystems in Europe changing the nutrient status of lakes (Renberg et al., 2001; Bradshaw et al., 2005). The latter study shows that diatom-inferred TP levels increased about 5 times (from c. $20 \mu \mathrm{g} / \mathrm{l}$ to consistently $>100 \mu \mathrm{g} / \mathrm{l}$ ) associated with major changes in agriculture during the Medieval period in Lake Dallund SØ, Denmark (Bradshaw et al., 2005). For comparison, the annual mean TP value in that lake was $65.9 \mu \mathrm{g} / \mathrm{l}$ in 1998 (Bradshaw et al., 2005). A similar study of Lake Mälaren (the third largest lake in Sweden, which drains into the Baltic Sea via the Stockholm archipelago) suggests moderately nutrient rich conditions, i.e. 10-20 $\mu \mathrm{g} / \mathrm{l} \mathrm{TP}$, during Medieval time followed by more nutrient rich conditions after c. 1850 with eutrophication accelerating around 1950 reaching TP values of c. 30-40 $\mu \mathrm{g} / \mathrm{l}$ in the late 1960's (Renberg et al., 2001).

\subsection{Land use changes}

The change from a one-field agrarian system to a two-field system, with fallow every second year, was gradually introduced to large areas in Sweden around 1000 AD (Myrdal, 1997). The first soil-inverting moldboard plow facilitated the introduction of this system with regular fallow. A similar connection between a change of cropping system and change of plowing implement is also valid for Denmark (Poulsen, 1997) and Germany (Simms, 1976) and most probably for the vast majority of the Baltic countries. Regular fallows meant that large areas lacked a permanent vegetation cover during long time-periods (i.e. no catch crops) leading to increased soil erosion and less nutrient uptake by plants (Myrdal, 1997). A regular fallow also had to be combined with a massive reclamation of land. The transition to a twofield system meant that, if the sown area was not to be reduced, then the extent of arable land had to be doubled, e.g. a 1 ha field in the old one-field system would require a 2 ha field in the new system. The introduction of the two-field system thus occurred contemporaneously with an expansion of the cultivated area. A doubling of the arable land during the Medieval expansion has been reported from palaeoecologcal studies in e.g. southern Sweden (Berglund et al., 1991). Similar estimates have been proposed from studies based on

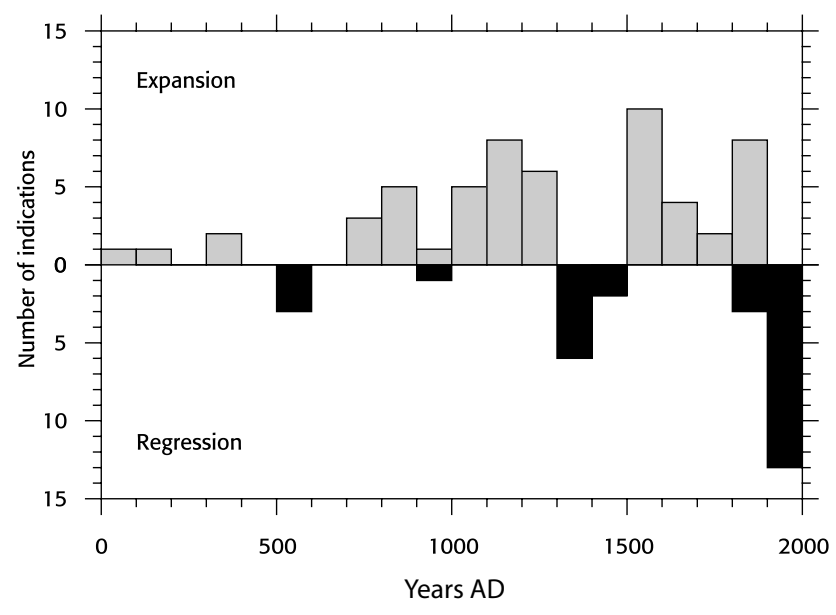

Fig. 5. Indicators of land-use expansion and regression during the last 2000 years in Southern Sweden (Lagerås, 2006). The figure shows distinctive expansions during the early-Medieval period between 700-1300 AD and between 1500-1900 AD (which overlaps with the Industrial Revolution). The late Medieval crisis (1300$1500 \mathrm{AD}$ ) is characterized by a marked land-use regression phase.

population data e.g. Pongratz et al. (2008) showed that the area with cropland more than doubled in Europe between 800-1300 AD (from c. 20 million ha to c. 50 million ha).

To meet the demand for more arable land for cultivation, the clearance of forests and grasslands became a general practice (Berglund et al., 1991; Myrdal, 1997; Lagerås, 2007; Fig. 5). Clearance was common in both established and marginal agricultural areas in Northwest Europe. Archaeological and historical data indicate that remote parts in the eastern Baltic region were in a period of general demographic and economic expansion around 800-1300 AD (Taavitsainen et al., 1998; Stanèikaite et al., 2009). There is evidence of intensive human impact starting around AD 900 in northwestern Lithuania, eastern Baltic region (Stanèikaite et al., 2009). The most prominent early agricultural activity has been dated to c. 1050-1250 AD, when forested areas were converted into cultivated fields and settled agriculture developed (Stanèikaite et al., 2009). Furthermore, palaeoecological studies from the remote eastern interior of Finland reveal an exponential rise in cereal pollen concentrations at the turn of the last millennia, indicating significant increase of arable land during the early Medieval expansion (Taavitsainen et al., 1998). Expansion of arable land in remote regions likely developed in a wide area of the northern boreal forests (Taavitsainen et al., 1998).

During the population expansion at the beginning of the Industrial Revolution (in the 18th and 19th century) the area of arable land in Sweden increased with c. $60 \%$. The greatest area of arable land in Sweden occurred in $1920 \mathrm{AD}$, i.e. 3.8 million ha (Morell, 2001) when the Swedish population reached c. 6 million (c. 0.6 ha per person) followed by a large decline after $1960 \mathrm{AD}$ in association with the 
introduction of synthetic fertilizers (Morell, 2001). In Europe, the pre-industrial (pre-1700 AD) estimate average c. 0.63 ha agricultural land (cropland) per person (Pongratz et al., 2008). By assuming that agricultural area is inherently linked to population, the historic estimate of c. 0.6 ha arable land per person would scale up to about 2.8 million ha arable land in the Baltic Sea drainage area around $1000 \mathrm{AD}$ (i.e. 4.6 million inhabitants $\times 0.6 \mathrm{ha}$ ) and 5.7 million ha around $1300 \mathrm{AD}$ with the expected Medieval population increase (9.5 million inhabitants $\times 0.6 \mathrm{ha}$ ).

Previous studies have shown nutrient losses to occur with plowing with up to 4 tonnes organic $\mathrm{Nha}^{-1}$ released after plowing permanent grassland (Fig. 4). If one applies this estimate to the estimated increase in arable land in the Baltic Sea area during the Medieval expansion (c. 2.9 million ha) it would generate 11.6 million tonnes of organic nitrogen release just from plowing. For comparison, average annual Ninputs to the Baltic Sea over the period 1997-2003 amounted 737000 tonnes. We do not know how rapid these N-losses may have occurred, which means that we do not know the rate of change, or the availability of N. However, the result demonstrates that the nutrient release from plowing must have been significant during the Medieval expansion. One has also to account for supplementary significant soil organic $\mathrm{C}$ and $\mathrm{P}$-discharges during plowing, $\mathrm{C}, \mathrm{N}, \mathrm{P}$-release from deforestation when reclaiming new land and from continuous annual manure of the fields to improve harvest. The presented number (i.e. 11.6 million tonnes of organic $\mathrm{N}$ ) is only a minimum estimate of one, out of many, potential anthropogenic nutrient sources. We therefore suggest that a rapid release of nutrients from land during the Medieval expansion triggered hypoxia in the Baltic Sea - and once established - it increased the internal P-load and blooms of cyanobacteria. Hypoxia during the Medieval time period could thus be an ancient analogue to the modern situation, where rapid increases in nutrient loads has resulted in widespread bottom water oxygen deficiency.

It can, however, be expected that during pre-historical and historical times, watersheds and streams were not extensively drained as at present with in-stream water residence time and nutrient retention rates probably greater. Nutrient retention in aquatic systems varies primarily with the physical properties of the water body, i.e. the size of the water body, and on flow conditions. Nitrogen removal by denitrification and settling decreases in deeper channels, where contact of stream water with bottom sediments is reduced. In-stream nutrient retention is higher in shallower channels and in streams with a long water residence time. Modeling studies of a modern watershed in Finland, with $60 \%$ covered by forest and several natural lakes that drain into the Baltic Sea, obtained an estimated retention of $24 \%$ for total $\mathrm{N}$ and $51 \%$ for total $\mathrm{P}$ (Grizzetti et al., 2003). Consequently, parts of the soil nutrient losses presented here would be retained in the watershed and not reach the sea. Unfortunately, the lack of published data on pre-historical and historical water residence times in the Baltic Sea watershed makes it difficult to estimate past nutrient retention rates. An accurate understanding and model representation of past nutrient transport and retention processes are needed to quantify historical nutrient loads from the catchment to the Baltic Sea.

The next great agrarian revolution was during the Industrial Revolution starting around $1850 \mathrm{AD}$ in northwestern Europe. Again, the European population increased rapidly (about 6 times between 1700-2005 AD; Table 1) and technological advances in agriculture and forestry exploded, in which the use of P-rich fertilizers was an important part. For a second time, the arable area in Europe more than doubled over a time period of c. $200 \mathrm{yr}$ (i.e. between c. 1700 1920 AD; Pongratz et al., 2008). Another important cause was tiling, which provided a pathway by which water on the fields was rapidly drained away and discharged into nearby waters. It has been demonstrated that in Swedish catchment areas with tile-drained fields, particulate $\mathrm{P}$ can amount $80 \%$ of the total $\mathrm{P}$ in downstream waters, with about half of the fraction becoming bio-available (Olli et al., 2009). The use of steel moldboard plows expanded rapidly with the introduction of the steam tractor during the first half of the 20th century (Lal et al., 2007). Agricultural production increased and in the 19th century and the forest industry rapidly expanded, especially in Sweden and Finland. Between c. $1830 \mathrm{AD}$ and 1880 Swedish and Finnish export of wood increased about 3-4 times (Larsson and Olsson, 1992). The forests were heavily exploited and numerous saw mills were built along the main rivers in Fennoscandia (Schybergson, 1974). Significant changes in diatom assemblages attributed to eutrophication dated to c. 1850-1900 AD have been observed in e.g. the southern Baltic Sea (Andrén et al., 1999). Numerous studies have demonstrated increased nutrient runoff and increased primary production in estuaries and coastal marine environments elsewhere during periods of population growth and increases in arable land area (Billen and Garnier, 1997; Boynton et al., 1995; Cooper and Brush, 1993; Nixon, 1997; Turner and Rabalais, 2003).

The onset of the modern agricultural revolution with the introduction of synthetic fertilizer (rich in both $\mathrm{P}$ and $\mathrm{N}$ ) occurred in the 1940's accelerating in the 1950's. The intense use of synthetic fertilizer is the direct cause for the increased nutrient load to the Baltic Sea over the last c. five decades, with the consequent of amplified eutrophication, expanded the hypoxic zone (c. 4 times since 1960; Jonsson et al., 1990) and increased the blooms of cyanobacteria.

Reconstruction of past nutrient loads to the Baltic Sea due the expansion of the human population and the development of agriculture is sorely needed. By combining estimates of population growth with a reconstruction of global agricultural areas and land-cover (Pongratz et al., 2008; Gaillard et al., 2010), estimates of nutrient leakage from the Baltic Sea watershed could be calculated and would allow us to approximate the historical changes in nutrient loads. 


\section{Cyanobacteria abundance in the Baltic Sea}

Blooms of cyanobacteia comprised of Aphanizomenon spp. and the $\mathrm{N}_{2}$-fixing cyanobacteria Nodularia spumigena are recurrent phenomena in the Baltic Sea during summer. The areal extent, duration and intensity of cyanobacteria differ greatly from year to year, especially for $N$. spumigena which form prominent surface accumulations (Kahru et al., 2007). A historical compilation of water column records since 1887 shows that the abundance of cyanobacteria was low prior to World War II (Finni et al., 2001). However, since the 1960s, blooms of cyanobacteria have been common in the open sea in both the Baltic Proper and the Gulf of Finland (Finni et al., 2001).

The fossil pigment record in sediments provides insight into the long-term historical changes that have occurred in the Baltic Sea beyond the modern time period with water column phytoplankton records. Rapid increases in zeaxanthin, a particularly stable biomarker for cyanobacteria, occurred during the transition from the Ancylus Lake to a brackish marine system during the Littorina (Bianchi et al., 2000; Westman et al., 2003). Excess P released during the transition from a freshwater to a marine system probably caused wide-spread cyanobacteria blooms (Bianchi et al., 2000). The presence of low levels of zeaxanthin throughout their piston core suggested that cyanobacteria had been present throughout the geological history (Bianchi et al., 2000), although the upper modern period was likely lost during core sampling. The presence of zeaxanthin was interpreted that $\mathrm{N}$-fixing cyanobacteria were a characteristic, natural feature of the Baltic Sea. Poutanen and Nikkilä (2001) used myxoxanthin and echinenone, also cyanobacteria specific pigments, in addition to zeaxanthin to examine historical trends in cyanobacteria abundance in three sediment cores. They showed that the occurrence and intensity of cyanobacteria blooms were seldom recorded before World War II (Poutanen and Nikkilä, 2001) similar to the finding in the water column records (Finni et al., 2001).

Cyanobacteria are common during summer in the Baltic Sea today due to excess dissolved inorganic phosphorus (DIP) left over after the spring bloom of phytoplankton depletes available dissolved inorganic nitrogen (Vahtera et al., 2007). The frequency of accumulation of cyanobacteria blooms has been positively correlated with the residual phosphate concentration after the spring bloom in May-June (Kahru et al., 2007). In a historical perspective, cyanobacteria blooms should be prevalent during periods of hypoxia due to the release of DIP from sediments and higher water column DIP concentrations (Conley et al., 2002). Certainly, during periods of historical hypoxia described above (Zillén et al., 2008) the sediment release of DIP was higher and one could hypothesize that cyanobacteria blooms were present.

One important question is: were DIP concentrations high enough during periods when the Baltic was oxic to create conditions favorable for cyanobacteria; as suggested by
Bianchi et al. (2000)? Given that there are no large-scale geological phosphorus deposits in the watershed, and that there is abundant iron in the northern Baltic Sea that has the ability to sequester phosphorus in sediments when the water column is oxic, there is no evidence to suggest that DIP concentrations would have been be high enough to create conditions favorable for cyanobacteria. We, therefore, hypothesize that cyanobacteria blooms were present primarily during periods of hypoxia and, therefore, they are not a natural feature of the Baltic Sea. This could be tested by examining sediment pigments during periods of hypoxia and when bottom water oxygen is present, although enhanced preservation of pigments during hypoxic periods will interfere with the interpretation.

\section{Discussion}

\subsection{Human impact and climate change}

This is the first study to focus on long-term trends in human activities and their relation to Baltic Sea ecosystem responses. The changes in population growth, technological development and land-use changes during the last two millennia can be linked to observed shifts in oxygen conditions in the bottom waters of the Baltic Proper (Fig. 2). The view that the Baltic Sea is a basin relatively unaffected by human perturbations prior to the last century and that the Baltic naturally has experienced prolonged hypoxia throughout its history is not supported by the data we have reviewed. The large mobility of nutrients $(\mathrm{C}, \mathrm{N}$ and $\mathrm{P})$ in association with changes in land-use and agricultural practices that had such substantial impacts on the nutrient status of lakes (Renberg et al., 2001; Bradshaw et al., 2005) must have affected the Baltic Sea and shifted it beyond a pristine state. Therefore, hypoxia in the Baltic Sea on pre-historical and historical time-scales cannot be considered to be fully natural.

The increase in salinity during the change from the Ancylus Lake to the Littorina Sea c. 8000 cal yr BP allowed for the sediment release of $\mathrm{P}$ creating favorable conditions for cyanobacterial blooms (Bianchi et al., 2000; Westman et al., 2003). The high salinity during the next 4000 years allowed for enhanced stratification, a shallowing of the halocline and sustained hypoxia (Zillén et al., 2008). The internal P-cycling plays a key role in the nutrient status of the basin (Conley et al., 2002; Mort et al., 2010). During oxic bottom water conditions, Fe-oxide bound $\mathrm{P}$ in surface sediments in the Baltic Sea acts as a major internal sink of $\mathrm{P}$ (e.g. Mort et al., 2010). The geological records show that during the early and more saline phase of the Littorina Sea, the hypoxic zone extended to the northern Baltic Sea (Zillén et al., 2008) which today is mostly oxic and acts as a major sink for P. Consequently, the area acting as an internal sink for $\mathrm{P}$ was much smaller at that time, compared to today, leading to a decreased internal P-sink on a basin-wide scale. The 
physical properties and the geochemical cycling during this early phase of the basins development were therefore significantly different from the late Holocene and the present situation. The subsequent changes in the morphology and depths of the Baltic basin around 4000 cal yr BP, especially the sills in the Danish Straits, reduced salinity (Gustafsson and Westman, 2002) diminished the halocline in the northern Baltic Sea, enhanced ventilation of bottom waters and enlarged the internal sink of $\mathrm{P}$ and terminating hypoxia. Therefore, the main driver for millennial scale changes in hypoxia during the early Holocene was natural.

Temperature has often been suggested as the key factor that triggers the formation of cyanobacteria blooms (Pearl and Huisman, 2008). Hypoxic periods during the late Holocene do overlap with climate anomalies, such as, the MWP (800-1200 AD; Lamb, 1965) when Northern Hemisphere annual mean temperatures were maximum c. $0.2-0.4^{\circ}$ warmer than today (or relative to the time period 1850-1995; Mann et al., 2008) and with the warming trend of most of the 20th century (Mann et al., 2008). However, the global distribution of hypoxia shows no relationship to temperatures but matches well the level of human influence (Diaz and Rosenberg, 2008). Temperature has also no proven effect on the oxygen conditions in the Baltic Sea and the relationship between primary production and climate change is not linear (Richardson and Schoeman, 2004). The link between phytoplankton abundance and sea surface temperature is only indirectly coupled to temperature. The same is true for the formation of cyanobacteria blooms in the Baltic Sea. The blooms only occur in warmer years when the vertical mixing depth of the water column does not exceed the critical depth (i.e. the depth below which cyanobacteria are unable to photosynthesize), which occurs during summer months when thermal stratification is present (Stal et al., 2003). The temperature effect is therefore only a contributory factor, since it causes a stabilization of the water column and decreasing the mixing depth, thereby increasing the light irradiance needed for the growth of cyanobacteria (Stal et al., 2003).

There is evidence that the MWP was markedly dryer than the following LIA in Europe. Dry conditions during the MWP are supported by European dendroclimate precipitation reconstructions (Helama et al., 2009) and tree-line and lake-level reconstructions in the Kola Peninsula, Russia (Kremenetski et al., 2004) where submerged tree-stumps of medieval age indicate severe drought with low lake-levels during this time period followed by wetter conditions. Increased storminess with frequent passages of cyclones during the LIA has been reconstructed from sand-drift studies in a variety of places in North West Europe (de Jong et al., 2006; Aagaard et al., 2007; Clarke and Rendell, 2009) suggesting a change to a windier and wetter climate regime during the LIA climate anomaly. We know from observations (Meier and Kauker, 2003) and modeling exercises (Meier, 2005) that the lower salinities and improved oxygen conditions during the stagnation periods in the $1920 / 1930$ s and particularly in the 1980/1990s can be explained by larger than normal freshwater inputs and reduced saltwater inflows. However, on longer time-scales ( $>30$ years) changes in freshwater and saltwater inflows cause the system to shift into a new steady state, in which the depth of the halocline and the stratification does not change significantly (Meier, 2005). It has been shown that the major physical factor affecting the stratification, the age and thus the ventilation of the Baltic Sea deep water on long time scales is not changes in freshwater/saltwater inflows but changes in wind speed (Meier, 2005). It can thus be hypothesized that increased storminess during the LIA could have increased the energy flux from winds, enhancing vertical mixing and deep water ventilation, ultimately leading to decreased hypoxic area in the Baltic Sea.

However, the nature of the MWP and LIA in Europe is still debated. Another view argues that there was a persistent positive NAO (North Atlantic Oscillation) during the MWP and a shift to weaker NAO conditions during the LIA in Europe, based on tree-ring drought reconstructions from Morocco and speleotherm-based precipitation proxy for Scotland (Trouet et al., 2009). Such conditions would, according to the above discussion, counteract the development of hypoxia during the MWP. In addition, the ecological response to NAO has been reviewed and several correlations between climate and ecological changes have been observed, although the mechanisms behind them are not understood (e.g. Ottersen et al. 2001). Along the Swedish west coast a strong correlation between phytoplankton biomass and NAO has been found, possibly caused by an increased stratification in Skagerrak (Belgrano et al., 1999). In the North Sea there has been an increase in phytoplankton season length and abundance since the mid 1980's, which is interpreted as a response to climatic forcing (Reid et al., 1998). Although NAO is well known to influence climate conditions in the Baltic Sea during the last c. $100 \mathrm{yr}$, no direct links between NAO, hypoxia and inflow of salt water have been firmly established.

It is noteworthy that the Baltic Sea stayed fully oxic for two thousand years before hypoxia developed during the Medieval period (Zillén et al., 2008) even though large climate variability occurred during that time period e.g. the Roman Warm Period (200 BC-400 AD) and the cold Dark Ages (400-600 AD). We therefore argue that, large scale land-use changes in the Baltic Sea watershed are just a strong potential independent forcing mechanism on increased productivity and hypoxia as climate changes during the late Holocene history of the Baltic Sea. However, long-term Baltic Sea ecosystem responses are probably due to multiple stressors and complex interplays between various terrestrial and marine processes, where both climate and human impacts may have interacted. Further studies are needed to identify and quantify hypoxia related processes to determine the relative importance of the two driving mechanisms, where long-term human impacts upon terrestrial and aquatic ecosystems must be included. Combined studies that use regional models of 
past anthropogenic land-cover change (Gaillard et al., 2010) and large-scale hydrological models of past land-sea nutrient inputs and fluxes (Humborg et al., 2007) should play an important role in this context.

\subsection{Management implications}

Large-scale changes in basin morphology, salinity and temperature, as during the early phase of the Littorina Sea, have not been observed in the Baltic Sea since. It is not relevant to today's discussion regarding the causes of hypoxia today in the Baltic to compare hypoxia that occurred 8000 4000 cal yr BP when environmental and morphological conditions were completely different.

We can conclude that blooms of nitrogen-fixing cyanobacteria during the late Holocene are not a natural feature of the Baltic Sea as claimed by Bianchi et al. (2000). Blooms of cyanobacteria are more likely connected to hypoxia due to the release of phosphorus from bottom sediments (Kahru et al., 2000, 2007; Vahtera et al., 2007). In addition, given the large scale changes in land use and the development of agriculture and population growth over the last two millennia it is doubtful that the Baltic Sea could have been an oligotrophic clear water sea ca. 1900 AD (Österblom et al., 2007; Savchuk et al., 2008). It is more likely that the Baltic Sea has become progressively eutrophic over the last two millennia with rapid ecosystem changes occurring in the ecosystem since the 1950s due to rapid increases in nutrient loading (Poutanen and Nikkilä, 2001; Österblom et al., 2007).

It follows that a goal for the restoration of the Baltic Sea must be to reduce the intensity and size of hypoxia in bottom waters. The present agreed-upon goal in the Baltic Sea Action Plan for nutrient reductions (HELCOM, 2007) cannot be expected to eliminate hypoxia and cyanobacteria blooms, but only to reduce their size (Wulff et al., 2007). Thus, the goal of restoration is not to return the ecosystem back to natural conditions, but to ensure that the dynamics of natural ecosystem processes are again operating efficiently so that both ecosystem structure and function can be recovered (National Research Council, 1992).

Acknowledgements. This work was supported by a grant from Baltic Sea 2020 (http://www.balticsea2020.org) and by a Marie Curie Chair to DJC (MEXC-CT-2006-042718). We thank Per Lagerås and Thomas Bianchi for comments on earlier versions of the manuscript. We also acknowledge the valuable reviews from Maren Voss and an anonymous referee. This is a contribution from the BONUS project HYPER (Contract No. 210-2008-1896).

Edited by: C. Heinze

\section{References}

Aagaard, T., Orford, J., and Murray, A. S.: Environmental controls on coastal dune formation, Skallingen Spit, Denmark, Geomorphology, 83, 29-47, 2007.

Andersson Palm, L.: Livet, kärleken och döden, (Live, Love and Death), L Palm, Historiska institutionen, Gothenburg, Sweden, 203 pp., 2001.

Andrén, E.: Changes in the composition of the diatom flora during the last century indicate increased eutrophication of the Oder Estuary, South-western Baltic Sea, Estuar. Coast. Shelf S., 48, 665-676, 1999.

Andrén, E., Andrén, T., and Kunzendorf, H.: Holocene history of the Baltic Sea as a background for assessing records of human impact in the sediments of the Gotland Basin, Holocene, 10, 687-702, 2000.

Antonson, H.: The extent of farm desertion in central Sweden during the late medieval agrarian crisis: landscape as a source, J. Hist. Geogr., 35, 619-641, 2009.

Belgrano, A., Lindahl, O., and Hernroth, B.: North Atlantic Oscillation primary productivity and toxic phytoplankton in the Gullmar Fjord, Sweden (1985-1996), P. Roy. Soc. Lond. B Bio., 266, 425-430, 1999.

Berglund, B. E., Larsson, L., Lewan, N., Olsson, G. A., and Skansjö, S.: Ecological and social factors behind the landscape changes, in: The cultural landscape during the 6000 years in southern Sweden - the Ystad Project, edited by: Berglund, B E., Ecol. Bull., 41, 425-445, 1991.

Berglund, B. E., Sandgren, P., Barnekow, L., Hannon, G., Jiang, H., Skog, G., and Yu, S. Y.: Early Holocene history of the Baltic Sea, as reflected in coastal sediments in Blekinge, southeastern Sweden, Quatern. Int., 130, 111-139, 2005.

Bianchi, T. S., Engelhaupt, E., Westman, P., Andrén, T., Rolff, C., and Elmgren, R.: Cyanobacterial blooms in the Baltic Sea: Natural or human induced?, Limnol. Oceanogr., 45, 716-726, 2000.

Billen, G. and Garnier, J.: The Phison River plume: coastal eutrophication in response to changes in land use and water management in the watershed, Aquat. Microbiol. Ecol., 13, 3-17, 1997.

Björck, S.: A review of the history of the Baltic Sea, 13.0-8.0 ka BP. Quatern. Int., 27, 19-40, 1995.

Björck, S.: The late Quaternary development of the Baltic Sea basin, in: Assessment of climate change for the Baltic Sea Basin, edited by: The BACC author Team, Springer-Verlag, Berlin, Heidelberg, 398-407, 2008.

Boynton, W. R., Garber, J. H., Summers, R., and Kemp, W. M.: Inputs, transformations and transport of nitrogen and phosphorus in Chesapeake Bay and selected tributaries, Estuaries, 18, 285314, 1995.

Bradshaw, E. G., Rasmussen, P., Nielsen, H., and Andersen, N. J.: Mid- to Late-Holocene land change and lake development at Dallund Sø, Denmark: trends in lake primary production as reflected by algal and macrophyte remains, Holocene, 15, 1130 1142, 2005.

Cameron, K. C. and Haynes, R. J.: Retention and movements of nitrogen in soils, in: Mineral nitrogen in the plant/soil system, edited by: Haynes, R. J., Academic Press, New York, 166-241, 1986.

Clarke, M. L. and Rendell, H. M.: The impact of North Atlantic storminess on western European coasts: A review, Quatern. Int., $195,31-41,2009$. 
Conley, D. J., Humborg, C., Rahm, L., Savchuk, O. P., and Wulff, F.: Hypoxia in the Baltic Sea and basin-scale changes in phosphorous and biogeochemistry, Environ. Sci. Technol., 36, 53155320, 2002.

Conley, D. J., Björck, S., Bonsdorff, E., Destouni, G., Gustafsson, B., Hietanen, S., Kortekaas, M., Kuosa, H., Meier, M., MüllerKarulis, B., Nordberg, K., Nürnberg, G., Norkko, A., Pitkänen, H., Rabalais, N., Rosenberg, R., Savchuk, O., Slomp, C. P., Voss, M., Wulff, F., and Zillén, L.: Hypoxia related processes in the Baltic Sea, Environ. Sci. Technol., 43, 3412-3420, 2009a.

Conley, D. J., Paerl, H. W., Howarth, R. W., Boesch, D. F., Seitzinger, S. P., Havens, K. E., Lancelot, C., and Likens, G. E.: Controlling eutrophication by reducing both nitrogen and phosphorus, Science, 323, 1014-1015, 2009b.

Cooper, S. R. and Brush, G. A.: A 2,500-year history of anoxia and eutrophication in Chesapeake Bay, Estuaries, 16, 617-626, 1993.

Dawson, J. J. C. and Smith, P.: Carbon losses from soil and its consequences for land-use management, Sci. Total Environ., 382, 165-190, 2007.

de Jong, R., Björck, S., Björkman, L., and Clemmensen, L. B.: Storminess variation during the last 6500 years as reconstructed from an ombrotrophic peat bog in Halland, southwest Sweden, J. Quarternary Sci., 21, 905-919, 2006.

Diaz, R. J. and Rosenberg, R.: Spreading dead zones and consequences for marine ecosystems, Science, 321, 926-929, 2008.

Feller, M. C.: Deforestation and nutrient loading to fresh waters, Encyclopedia of Inland Waters, 29-44, 2009.

Finni, T., Kononen, K., Olsonen, R., and Wallström, K.: The history of cyanobacterial blooms in the Baltic Sea, Ambio, 30, 172-178, 2001.

Freibauer, A., Rounsevell, M. D. A., Smith, P., and Verhagen, J.: Carbon sequestration in the agricultural soils of Europe, Geoderma, 122, 1-23, 2004.

Gaillard, M.-J., Sugita, S., Mazier, F., Trondman, A.-K., Broström, A., Hickler, T., Kaplan, J. O., Kjellström, E., Kokfelt, U., Kuneš, P., Lemmen, C., Miller, P., Olofsson, J., Poska, A., Rundgren, M., Smith, B., Strandberg, G., Fyfe, R., Nielsen, A. B., Alenius, T., Balakauskas, L., Barnekow, L., Birks, H. J. B., Bjune, A., Björkman, L., Giesecke, T., Hjelle, K., Kalnina, L., Kangur, M., van der Knaap, W. O., Koff, T., Lagerås, P., Latalowa, M., Leydet, M., Lechterbeck, J., Lindbladh, M., Odgaard, B., Peglar, S., Segerström, U., von Stedingk, H., and Seppä, H.: Holocene land-cover reconstructions for studies on land coverclimate feedbacks, Clim. Past, 6, 483-499, doi:10.5194/cp-6483-2010, 2010.

Grizzetti, B., Bouraoui, F., Granlund, K., Rekolainen, S., and Bidoglio, G.: Modelling diffuse emission and retention of nutrients in the Vantaanjoki watershed (Finland) using the SWAT model, Ecol. Model., 169, 25-38, 2003.

Gustafsson, B. G. and Westman, P.: On the causes of salinity variations in the Baltic Sea during the last 8500 years, Paleocenography, 17, 1-14, 2002.

HELCOM: Baltic Sea Action Plan, 101 pp., 2007.

Helama, S., Meriläinen, J., and Tuomenvirta, H.: Multicentennial megadrought in northern Europe coincided with a global El Niño Southern Oscillation drought pattern during the Medieval Climate Anomaly, Geology, 2, 175-178, 2009.
Humborg, C., Mörth, C.-M., Sundbom, M., and Wulff, F.: Riverine transport of biogenic elements to the Baltic Sea - past and possible future perspectives, Hydrol. Earth Syst. Sci., 11, 1593-1607, doi:10.5194/hess-11-1593-2007, 2007.

Jonsson, P., Carman, R., and Wulff, F.: Laminated sediments in the Baltic - a tool for evaluating nutrient mass balance, Ambio 19, 152-158, 1990.

Kahru, M., Leppänen, J.-M., Rud, O., and Savchuk, O. P.: Cyanobacteria blooms in the Gulf of Finland triggered by saltwater inflow into the Baltic Sea, Mar. Ecol.-Prog. Ser., 207, 13-18, 2000.

Kahru, M., Savchuk, O. P., and Elmgren, R.: Satellite measurements of cyanobacterial bloom frequency in the Baltic Sea: interannual and spatial variability, Mar. Ecol.-Prog. Ser., 343, 15-23, 2007.

Kaplan, J. O., Krumhardt, K. M., and Zimmermann, N.: The prehistoric and preindustrial deforestation of Europe, Quaternary Sci. Rev., 28, 3016-3034, 2009.

Karlson, K., Rosenberg, R., and Bonsdorff, E.: Temporal and spatial large-scale effects of eutrophication and oxygen deficiency on benthic fauna in Scandinavian and Baltic waters - a review, Oceanogr. Mar. Biol., 40, 427-489, 2002.

Kremenetski, K. V., Boettger, T., MacDonald, G. M., Vaschalova, T., Sulerzhitsky, L., and Hiller, A.: Medieval climate warming and aridity as indicated by multiproxy evidence from the Kola Peninsula, Russia, Palaeogeogr. Palaeoclim. Palaeoecol., 209, 113-125, 2004.

Lagerås, P.: The ecology of expansion and abandonment, Medieval and post-Medieval land-use and settlement dynamics in a landscape perspective, Riksantikvarieämbetet, Sweden, 256 pp., 2007.

Lal, R.: Soil carbon sequestration impacts on global climate change and food security, Science, 305, 1623-1627, 2004.

Lal, R., Reicosky, D. C., and Hanson, J. D.: Evolution of the plow over 10,000 years and the rationale for no-till farming, Soil Till. Res., 93, 1-12, 2007.

Lamb, H. H.: Climate, history and the modern world, 2nd edition, Routledge, London, 433 pp., 1965.

Larsson, M. and Olsson U.: Industrialiseringens sekel, in: Sveriges industriförbund, Sveriges Industri, Gotab, Stockholm, 17-43, 1992.

Leipe, T., Dippner, J. W., Hille, S., Voss, M., Christiansen, C., and Bartholdy, J.: Environmental changes in the central Baltic Sea during the past 1000 years: inferences from sedimentary records, hydrography and climate, Oceanologia, 50, 23-41, 2008.

Likens, G. E. and Bormann, F. H.: Biogeochemistry of a forested ecosystem, 2nd edition, Springer-Verlag, New Yor, NY, 1995.

Löfgren, S., Ring, E., von Brömssen, C., Sørensen, R., and Högbom, L.: Short-term effects of clear-cutting on the water chemistry of two boreal streams in northern Sweden: A paired catchment study, Ambio, 38, 347-356, 2009.

Mann, M. E., Zhang, Z., Hughes, M. K., Bradley, R. S., Miller, S. K., Rutherford, S., and Ni, F.: Proxy-based reconstructions of hemispheric and global surface temperature variations over the past two millennia, P. Natl. Acad. Sci. USA, 105, 13252-13257, 2008.

McEvedy, C. and Jones, R.: Atlas of world population history, Penguin Books, Harmondsworth, UK, 19-119, 1978. 
Meier, H. E. M. and Kauker, F.: Sensitivity of the Baltic Sea salinity to the freshwater supply, Clim. Res., 24, 231-242, 2003.

Meier, H. E. M.: Modeling the age of Baltic Seawater masses: Quantification and steady state sensitivity experiments, J. Geophys. Res., 110, C02006, doi:10.1029/2004JC002607, 2005.

Morell, M.: Jordbruket i industrisamhället, Det svenska jordbrukets historia IV, Natur \& Kultur/LT, Stockholm, 392 pp., 2001.

Mort, H. P., Slomp, C. P., Gustafsson, B. G., and Andersen, T. J.: Phosphorus recycling and burial in Baltic Sea sediments with contrasting redox conditions, Geochim. Cosmochim. Acta, 74, 1350-1362, 2010.

Myrdal, J.: The agricultural transformation of Sweden, 1000-1300, in: Medieval farming and technology, The impact of agricultural change in Northwest Europe, edited by: Astill, G. and Langdon, J., Brill. Leiden, The Netherlands, 147-171, 1997.

National Research Council: Restoration of Aquatic Ecosystems: Science, Technology, and Public Policy, National Academy Press, Washington, DC, 1992.

Nixon, S. W.: Prehistoric nutrient inputs and productivity in Narragansett Bay, Estuaries, 20, 253-261, 1997.

Österblom, H., Hansson, S., Larsson, U., Hjerne, O., Wulff, F., Elmgren, R., and Folke, C.: Human-induced trophic cascades and ecological regime shifts in the Baltic Sea, Ecosystems, 10, 877889, 2007.

Olli, G., Darracq, A., and Destouni, G.: Field study of phosphorous transport and retention in drainage reaches, J. Hydrol., 365, 4655, 2009.

Ottersen, G., Planque, B., Belgrano, A., Post, E., Reid, P. C., and Stenseth, N. C.: Ecological effects of the North Atlantic Oscillation, Oecologia, 128, 1-14, 2001.

Pearl, H. W. and Huisman, J.: Blooms like it hot, Science, 320, 57-58, 2008.

Pongratz, J., Reick, C., Raddatz, T., and Claussen, M.: A reconstruction of global agricultural areas and land cover for the last millennium, Global Biogeochem. Cy., 22, GB3018, doi:10.1029/2007GB003153, 2008.

Poulsen, B.: Agricultural technology in medieval Denmark, in: Medieval farming and technology, The impact of agricultural change in Northwest Europe, edited by: Astill, G. and Langdon, J., Brill. Leiden, The Netherlands, 115-146, 1997.

Poutanen, E.-L. and Nikkilä, K.: Carotenoid pigments as tracers of cyanobacteria blooms in recent and post-glacial sediments of the Baltic Sea, Ambio, 30, 179-183, 2001.

Reid, P. C., Edwards, M., Hunt, H. G., and Warner, A. J.: Phytoplankton changes in the North Atlantic, Nature, 391, 546, 1998.

Renberg, I., Bindler, R., Bradshaw, E., Emteryd, O., and McGowan, S.: Sediment evidence of early eutrophication and heavy metal pollution in Lake Mälaren, Central Sweden, Ambio, 30, 496502, 2001

Richardson, A. J. and Schoeman, D. S.: Climate impact on plankton ecosystems in the Northeast Atlantic, Science, 305, 1609-1612, 2004.

Risberg, J.: Siliceous microfossil stratigraphy in a superficial sediment core from the north-western part of the Baltic Proper, Ambio, 19, 167-172, 1990.

Savage, C., Leavitt, P. R., and Elmgren, R.: Effects of land use, urbanization, and climate variability on coastal eutrophication in the Baltic Sea, Limnol. Oceanogr., 55, 1033-1046, 2010.
Savchuk, O. P., Wulff, F., Hille, S., Humborg, C., and Pollehne, F.: The Baltic Sea a century ago - a reconstruction from model simulations, verified by observations, J. Mar. Syst., 74, 485-494, 2008.

Schlesinger, W. H.: Better living through biogeochemistry, Ecology, 85, 2402-2407, 2004.

Schybergson, P.: Hantverk och fabriker III, Finland's consumer goods industry, 1815-1870: Statistics, Societas Scientiarum Fennica, Helsinki, 125 pp., 1974.

Simms, A.: Deserted medieval villages and fields in Germany. J. Hist. Geogr., 2, 223-238, 1976.

Smith, P., Smith, J. U., and Powison, D. S.: Moving the Brittish cattle herd, Nature, 381, 15, 1996.

Snowball, I. F., Korhola, A., Briffa, K. R., and Koç, N.: Holocene climate dynamics in Fennoscandia and the North Atlantic, in: Past climate variability through Europe and Africa, edited by; Battarbee, R. W., Gasse, F., and Stickley, C. E., Springer, Dordrecht, The Netherlands, 465-494, 2004.

Stal, L. J., Albertano, P., Bergman, B., von Bröckel, K., Gallon, J. R., Hayes, P. K., Sivonen, K., and Walsby, A. E.: BASIC: Baltic Sea cyanobacteria. An investigation of the structure and dynamics of water blooms of cyanobacteria in the Baltic Sea - responses to a changing environment, Cont. Shelf Res., 23, 1695-1714, 2003.

Stanèikaite, M., Šinkûnas, P., Risberg, J., Šeiriene, V., Blažauskas, N., Jarockis, R., Karlsson, S., and Miller, U.: Human activity and the environment during the Late Iron Age and Middle Ages at the Impiltis archaeological site, NW Lithuania, Quatern. Int., 203, 74-90, 2009.

Taavitsainen, J.-P., Simola, H., and Grönlund, E.: Cultivation history beyond the periphery: early agriculture in the North European boreal forest, J. World Prehist., 12, 199-253, 1998.

Trouet, V., Esper, J., Graham, N. E., Baker, A., Scourse, J. D., and Frank, D. C.: Persistent positive North Atlantic Oscillation mode dominated the Medieval Climate Anomaly, Science, 324, 78-80, 2009.

Turner, R. E. and Rabalais, N. N.: Linking landscape and water quality in the Mississippi River Basin for 200 years, Bioscience, 6, 563-572, 2003.

Ulèn, B., Bechmann, M., Fölster, J., Jarvie, H. P., and Tunney, H.: Agriculture as a phosphorus sourse for eutrophication in northwest European countries, Norway, Sweden, United Kingdom and Ireland: a review, 2007, Soil Use Manage., 23, 5-15, 2007.

Vahtera, E., Conley, D. J., Gustafsson, B. G., Kuosa, H., Pitkanen, H., Savchuk, O. P., Tamminen, T., Viitasalo, M., Voss, M., Wasmund, N., and Wulff, F.: Internal ecosystem feedbacks enhance nitrogen-fixing cyanobacteria blooms and complicate management in the Baltic Sea, Mar. Ecol.-Prog. Ser., 36, 186-194, 2007.

Voss, M., Kowalewska, G., and Brenner, W.: Microfossil and biogeochemical indicators of environmental changes in the Gotland Deep during the last 10000 years, Baltica, 14, 131-140, 2001.

Westman, P., Borgendahl, J., Bianchi, T. S., and Chen, N.: Probable causes for cyanobacterial expansion in the Baltic Sea: Role of anoxia and phosphorus retention, Estuaries, 26, 680-689, 2003.

Widerlund, A. and Andersson, P. S.: Strontium isotopic composition of modern and Holocene mollusc shells as a palaeosalinity indicator for the Baltic Sea, Chem. Geol., 232, 54-66, 2006. 
Whitmore, A. P., Bradbury, N. J., and Johnson, P. A.: Potential contribution of plowed grassland to nitrate leaching, Agric. Ecosyst. Environ., 39, 221-233, 1992.

Wulff, F., Savchuk, O. P., Solokov, A., Humborg, C., and Mörth, C.-M.: Management options and the effects on a marine ecosystem: Assessing the future of the Baltic Sea, Ambio, 36, 243-249, 2007.
Zillén, L., Conley, D. J., Andrén, T., Andrén, E., and Björck, S.: Past occurrences of hypoxia in the Baltic Sea and the role of climate variability, environmental change and human impact, Earth Sci. Rev., 91, 77-92, 2008. 